\title{
Genetic diversity and demographic history of the endemic Southeastern Pacific sea urchin Arbacia spatuligera (Valenciennes 1846)
}

\section{Diversidad genética e historia demográfica del erizo de mar endémico del Pacífico Sureste Arbacia spatuligera (Valenciennes 1846)}

\section{Constanza Millán ${ }^{1}$, Angie Díaz ${ }^{1,2, *}$, Elie Poulin²,3, Catalina Merino-Yunnissi ${ }^{4}$ \& Andrea Martínez ${ }^{4}$}

'Laboratorio de Ecología Molecular Marina (LEMMAR), Departamento de Zoología, Facultad de Ciencias Naturales y Oceanográficas, Universidad de Concepción, Concepción, Chile. IInstituto de Ecología y Biodiversidad (IEB), Departamento de Ciencias Ecológicas, Universidad de Chile, Santiago, Chile.

${ }^{3}$ Laboratorio de Ecología Molecular, Departamento de Ciencias Ecológicas, Facultad de Ciencias, Universidad de Chile, Santiago, Chile.

${ }^{4}$ Departamento de Zoología de Invertebrados, Museo Nacional de Historia Natural, Santiago, Chile.

*Email: angiediaz@udec.cl

\begin{abstract}
The pattern of the genetic structuring of marine species result from the relationship between homogenizing and structuring factors, together with historical and contemporary processes. Dispersal potential has been described as a homogenizing factor, corroborated by the connectivity paradigm, which states that high dispersers show low or no genetic differentiation. In contrast, biogeographic breaks and oceanic currents have an important role in limiting or enhancing connectivity, being structuring factors. We studied this relationship in Arbacia spatuligera, a subtidal echinoid with a planktonic larval stage, which is distributed along the Southeastern Pacific (SEP). The SEP is divided into two biogeographic provinces with an Intermediate Area between both them, which is delimited by two biogeographic breaks $\left(\sim 30^{\circ} \mathrm{S}\right.$ and $\left.40^{\circ}-42^{\circ} \mathrm{S}\right)$. Moreover, much of the SEP coast, from $\sim 42^{\circ} \mathrm{S}$ to $6^{\circ} \mathrm{S}$, it is influenced by a complex system of marine currents known as the Humboldt Current System (HCS). Using molecular tools (mtDNA COI) we assessed the genetic diversity and structure of A. spatuligera and inferred its demographic history. Analyses showed that along ca. $3.200 \mathrm{~km} \mathrm{A.} \mathrm{spatuligera} \mathrm{has} \mathrm{no} \mathrm{genetic}$ structure signals, has an unexpected low genetic diversity and a signal of recent demographic expansion dated $\sim 33000$ - 47000 years ago, probably related to the Marine Isotope Stage 3 (MIS3) climatic events. Our results support the hypothesis that dispersal potential is a determining factor of the phylogeographic patterns in the SEP, probably influenced by HCS. We propose that A. spatuligera is a high disperser.
\end{abstract}

Keywords: Biogeography, echinoids, dispersal potential, marine connectivity, phylogeography.

\section{RESUMEN}

El patrón de estructuración genética de especies marinas es resultado de la relación entre factores homogeneizadores y estructurantes, junto con procesos históricos y contemporáneos. El potencial de dispersión es descrito como un importante factor de homogeneización, corroborado por el paradigma de conectividad, que propone que altos dispersores mostrarán una baja o nula diferenciación genética. En contraste, los quiebres biogeográficos y corrientes oceánicas tienen un papel importante en limitar o facilitar la conectividad, siendo factores de estructuración. Hemos estudiado estas relaciones en Arbacia spatuligera, un equinoideo submareal con un estadio larvario planctónico, distribuido en el Pacífico Sudeste (PSE). EI PSE se divide en dos Provincias biogeográficas con un Área Intermedia entre ambas, delimitada por dos quiebres biogeográficos $\left(\sim 30^{\circ} \mathrm{S}\right.$ 
y $40^{\circ}-42^{\circ} \mathrm{S}$ ). Además, gran parte de la costa del PSE, desde $\sim 42^{\circ}$ a $6^{\circ} \mathrm{S}$ es influenciada por el Sistema de Corrientes de Humboldt (SCH). Utilizando herramientas moleculares (ADNmt COI), determinamos la diversidad y estructura genética de $A$. spatuligera e inferimos su historia demográfica. Los resultados mostraron que a lo largo de $\sim 3.200 \mathrm{~km} \mathrm{~A}$. spatuligera no presenta una señal de estructuración genética, posee una inesperada baja diversidad genética y una señal de expansión demográfica reciente ( 33000 - 47000 años atrás), probablemente relacionada con los eventos climáticos de la etapa 3 de Isótopos Marinos (MIS 3). Nuestros resultados apoyan la hipótesis del potencial de dispersión como un factor determinante de los patrones filogeográficos en el SEP, probablemente influenciado por el SCH. Proponemos que A. spatuligera es un alto dispersor.

Palabras clave: Biogeografía, conectividad marina, equinoideos, filogeografía, potencial dispersivo.

\section{INTRODUCTION}

Dispersion is an active or passive transport mechanism of individuals, at intra or inter-population level, and which depends on the intrinsic characteristics of the species and their habitat. In marine environments, benthic species generally have a period of active dispersion restricted to a stage of the life cycle, the larval phase (Palumbi 1996; Grosberg \& Cunningham 2001; Cowen \& Sponaugle 2009; Haye et al. 2014). This dispersive stage is a key factor, especially for species with sessile adults, because it determines the degree of connectivity between the populations of a species, defines its distribution and other patterns such as the relative abundance of each population (Palumbi 2003; Cowen \& Sponaugle 2009). Consequently, it is expected that species with a larval dispersal stage will show either low or no genetic differentiation among their populations, also called the "connectivity paradigm" (Scheltema 1971, 1986a, 1986b; Pechenik 1999; Grosberg \& Cunningham 2001; Palumbi 2003; Haye et al. 2014). Whereas this prediction has been supported by numerous studies (Todd et al. 1998; Bohonak 1999; Cárdenas et al. 2009; Zakas et al. 2009; Maltagliati et al. 2010; Ibañez et al. 2011; Haye et al. 2014), some species do not support the connectivity paradigm (Hereu et al. 2004; Sotka \& Palumbi 2006; Ayre et al. 2009; Pelc et al. 2009), despite having prolonged larval stage, and even in species that spend their entire life as part of the plankton.

Thereby, the genetic structure pattern of a species, defined as the distribution of alleles in a geographical range, is the result of the relationship between structuring (i.e., biogeographic breaks) and homogenizing factors (i.e., dispersal of adult propagules or larvae, rafting, among others) and the effects of the interaction between historical and contemporary processes (Palumbi 1996; Goldson et al. 2001; Grosberg \& Cunningham 2001; Gawarkiewicz et al. 2007; Haye et al. 2014). Therefore, the degree of genetic structure could provide useful information on historical and current connectivity between populations (Avise 2000; Pelc et al. 2009; Haye et al. 2014). In this sense, biogeographical breaks, defined as areas where the limit of the distributional range for a high number of species occur (Sánchez et al. 2011), can generate genetic signals detected as phylogeographic breaks. Meaning, intraspecific genetic differentiation due to past or present barriers that interrupt the gene flow of species (Wares \& Cunnigham 2001; Cárdenas et al. 2009; Pelc et al. 2009; Haye et al. 2014). Thereby, understanding of how historical and/or contemporary processes have determined the current distribution and abundance of species has been a long-standing scientific concern (Avise 2000).

\section{STUDY AREA}

The Southeastern Pacific (SEP) is an extended area defined from the Equator to the southern tip of South America. We recognize three regions from north to south: a year-round upwelling (from the equator to c. $30^{\circ} \mathrm{S}$ ), a seasonal upwelling (c. $30-40^{\circ} \mathrm{S}$ ) and the Patagonian Area (south of $40^{\circ} \mathrm{S}$ ), which is characterized by fjords and straits (Cárdenas et al. 2009). The region from $40^{\circ}-42^{\circ} \mathrm{S}$ to $6^{\circ} \mathrm{S}$ is influenced by a northward complex system of marine currents known as the Humboldt Current System (HCS), characterized by upwelling processes, that carry nutrient-rich waters to the surface from the bottom of the continental shelf (50-100 m deep) (Montecinos et al. 2005; Thiel et al. 2007; Ibáñez et al. 2011; Hooker et al. 2013). Thiel et al. (2007) identify four intense upwelling processes in the SEP (Mejillones, Antofagasta, Coquimbo and Concepción), whose influence allows the growth of marine prairies which feeds herbivores such as echinoids and gastropods (Hooker et al. 2013). Another characteristic of the coast of the SEP is the subsurface oxygen minimum zones (OMZs) (Ulloa \& Pantoja 2009), a drastic oxygen concentration decrease to levels < $20 \mu \mathrm{M}$ and even anoxia, due to the high primary productivity in surface waters and sluggish ventilation. This $\mathrm{OMZ}$ is quite thick $(\sim 500 \mathrm{~m})$ and its upper boundary varies: it is shallow (2550m) off the coasts of Peru and northern Chile, and deepens 
further south ( 100m off Concepción at $37^{\circ} \mathrm{S}$ ) (Atkinson et al. 2002; Fuenzalida et al. 2009).

The continental shelf of the SEP has a narrow and wedged shape in Northern Chile $\left(\sim 4.8-6.4 \mathrm{~km}\right.$ up to $\left.\sim 32^{\circ} \mathrm{S}\right)$, which progressively widening from $36^{\circ} \mathrm{S}$ until it reaches around 16 to $70 \mathrm{~km}$ (Bernal et al. 1982; Thiel et al. 2007). This zone is characterized by a sea bottom consisting of eroded rocky terraces, and deep and abrupt clines north of $32^{\circ} \mathrm{S}$, while south of $32^{\circ} \mathrm{S}$ it is made up of sedimentary basins. Due to the different distributional patterns and changes in biotic components, three biogeographic units have been described for the SEP, from North to South: i) The Peruvian Province $\left(4^{\circ} \mathrm{S}-30^{\circ} \mathrm{S}\right)$, characterized by temperate biota and permanent upwelling events; ii) the Intermediate Area $\left(30^{\circ} \mathrm{S}-42^{\circ} \mathrm{S}\right)$ with mixed character biota and seasonal upwelling, and iii) the Magellanic Province $\left(42^{\circ} \mathrm{S}-56^{\circ} \mathrm{S}\right)$ characterized by an austral/southern biota (Camus 2001; Cárdenas et al. 2009; Sánchez et al. 2011). Between these provinces and area, two biogeographic breaks occur. The first one is located at $\sim 30^{\circ} \mathrm{S}$ and its origins and determining environmental factors have not been clearly defined. The second one, located at $\sim 42^{\circ} \mathrm{S}$, is recognized as the main source of biogeographic discontinuity of the coastal line (Camus 2001), in which the Last Glacial Maximum was key to its establishment (Cárdenas et al. 2009).

\section{Study Model}

Among the diverse benthic fauna of the Southeastern Pacific, echinoderms stand out for their diversity, their ecological role as primary consumers and in most cases for having a complex life cycle that includes a dispersive larval phase (Smith 1997; McEdward \& Miner 2001; Moore 2006). Arbacia spatuligera (Valenciennes 1846) is an echinoid that inhabits the subtidal zone $(<30 \mathrm{~m}$, Larraín 1975$)$, distributed from Guayaquil $\left(\sim 2^{\circ} \mathrm{S}\right.$, Equator) to Puerto Montt ( $41^{\circ} \mathrm{S}$, Chile, Larraín 1975; Lessios et al. 2012). A. spatuligera has a complex life cycle with a planktonic larval phase of $\sim 30$ days, followed by settlement and metamorphosis into a benthic adult stage (Harvey 1956; Lessios et al. 2012). This species has no commercial value and is little known, with studies mainly focused in fertility/survival bioassays (Bay-Schmith 1981; Larraín et al. 1999). However, its dispersal potential conferred by the presence of a planktonic larval stage and a wide distribution range across Peruvian Province and the Intermediate Area of the SEP, make this species an interesting study model to evaluate the historical effects of geographical, oceanographic and climatic conditions on the genetic diversity pattern of marine benthic fauna.

Phylogeography interprets the spatial distribution of gene lineages, using mainly fragments of mitochondrial DNA (mtDNA), due to its fast-paced evolution, maternal inheritance and intraspecific polymorphism (Avise et al. 1987). In particular, the COI (Cytochrome Oxidase I) marker, has proved to be especially useful to allow the detection of historical and contemporary gene flow in many animal study models such as echinoids (i.e. Duran et al. 2004, Haye et al. 2014) and even concordance between phylogeographic and biogeographic breaks (Palumbi 1996; Lessios et al. 1999; Debenham et al. 2000; McCartney et al. 2000; Lessios et al. 2001, 2003; luri et al. 2007; Pelc et al. 2009; Haye et al. 2014). Therefore, using molecular tools (Cytochrome Oxidase I, mtDNA), the present study will determine the pattern of genetic diversity, genetic structure and reconstruct the demographic history of the species A. spatuligera in the SEP. Due to its dispersive larval phase and distribution range influenced by $\mathrm{SCH}$, we expect to detect a high genetic diversity and no signal of genetic structure despite the biogeographic scenario described for the SEP.

\section{MATERIALS AND METHODS}

\section{SAMPLE COLLECTION}

140 individuals of Arbacia spatuligera were collected by SCUBA diving $(10-30 \mathrm{~m})$ from 5 locations along the SEP

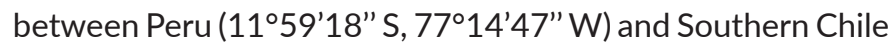
(36 $46^{\circ} 37^{\prime \prime}$ S, 73 $3^{\circ} 1^{\prime \prime} 13^{\prime \prime} \mathrm{W}$ ), during 2016 and 2018. According to the biogeographic scenario proposed for the SEP, these localities belong to the Peruvian Province ( $P P, N=4)$ and to the Intermediate Area (IA, N=1). All individuals sampled were fixed in $95 \%$ alcohol and carried to the laboratory for further analysis (Table 1, Fig. 1).

TABLE 1. Sampling localities of Arbacia spatuligera in the Southeastern Pacific. / Localidades de muestreo de Arbacia spatuligera en el Pacífico Sudeste.

\begin{tabular}{llcccc}
\hline Location & Group & N & Latitude & Longitude & Year \\
\hline Lima & Peruvian Province & 17 & $11^{\circ} 59^{\prime} 18^{\prime \prime} \mathrm{S}$ & $77^{\circ} 14^{\prime} 47^{\prime \prime} \mathrm{O}$ & 2018 \\
Arica & Peruvian Province & 18 & $18^{\circ} 27^{\prime} 11^{\prime \prime} \mathrm{S}$ & $70^{\circ} 19^{\prime} 18^{\prime \prime} \mathrm{O}$ & 2018 \\
Taltal & Peruvian Province & 29 & $25^{\circ} 23^{\prime} 23^{\prime \prime} \mathrm{S}$ & $70^{\circ} 30^{\prime} 57^{\prime \prime} \mathrm{O}$ & 2016 \\
Coquimbo & Peruvian Province & 46 & $29^{\circ} 57^{\prime} 50^{\prime \prime} \mathrm{S}$ & $71^{\circ} 21^{\prime} 11^{\prime \prime} \mathrm{O}$ & 2016 \\
Concepción & Intermediate Area & 30 & $36^{\circ} 45^{\prime} 37^{\prime \prime} \mathrm{S}$ & $73^{\circ} 10^{\prime} 13^{\prime \prime} \mathrm{O}$ & 2016 \\
\hline
\end{tabular}




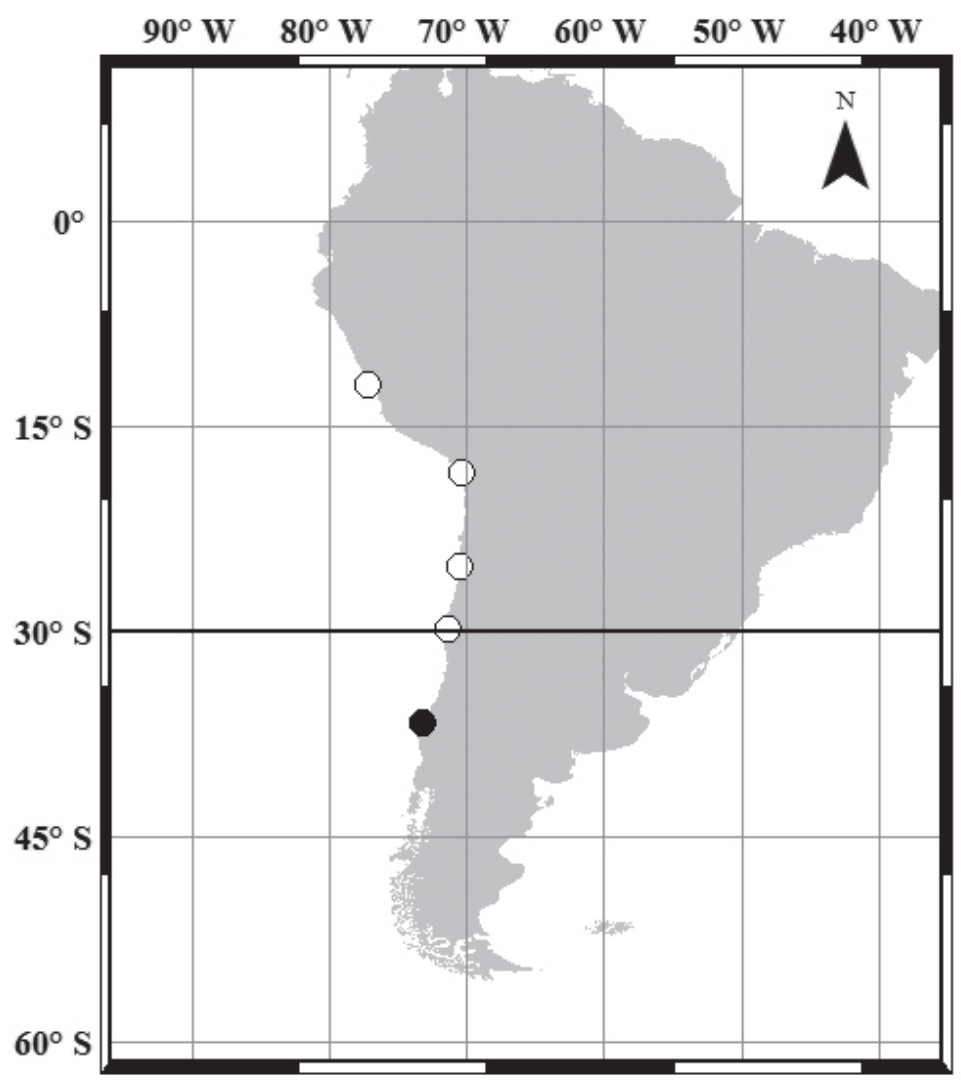

FIGURE 1. SEP sampling localities: Peruvian Province in white, Intermediate Area in black. / Localidades muestreadas en el PSE: Provincia Peruviana en blanco, Área Intermedia en negro.

\section{DNA PREPARATION AND SEQUENCING}

Total DNA was extracted from the gonadal tissue and spines using the Quick-DNA ${ }^{\mathrm{TM}}$ Miniprep Plus $\mathrm{Kit}^{\circledR}$ Zymo Research following the manufacturer's protocols. A partial sequence of $\mathrm{COI}$ was obtained using specific primers designed for sea urchins by Haye et al. (2014).PCR's were performed in a total volume of $25 \mu \mathrm{l}$ which includes $4 \mu \mathrm{l}$ of total DNA, $12.5 \mu \mathrm{l}$ of GoTaq ${ }^{\circledR}$ GreenMastermix 1X, $6.5 \mu$ l of ultrapure water and $1 \mu \mathrm{l}$ of each primer at $10 \mathrm{pmol}$. Cycling conditions initially consisted in denaturation at $94^{\circ} \mathrm{C}$ (during $10 \mathrm{~min}$ ), followed by 35 cycles of denaturation at $94^{\circ} \mathrm{C}(40 \mathrm{~s}), 58^{\circ} \mathrm{C}(40 \mathrm{~s})$ and $72^{\circ} \mathrm{C}$ (60s), and a $10 \mathrm{~min}$ of final extension at $72^{\circ} \mathrm{C}$. PCR products were purified using QIAquick Gel Extraction Kit (QIAGEN) and then automatically sequenced (Macrogen Inc.) Sequences were edited and aligned using Proseq version 3.5 (Filatov 2009), and translated to amino acids to check the presence of pseudogenes and/or sequencing errors with MEGA 6.0 (Tamura et al. 2013). All new sequences of $A$. spatuligera are available at Genbank (access codes MK382495 - MK382634).

\section{Genetic AnAlyses}

Diversity indexes

Standard diversity indices such as number of haplotypes $(\mathrm{H})$, number of polymorphic sites $(\mathrm{S})$, haplotype diversity $(\mathrm{Hd})$, mean number of pairwise differences ( $\mathrm{k}$ ) as well as nucleotide diversity $(\pi)$, were estimated for each group (PP and IA) using software DnaSP 5.0 (Librado \& Rosas 2009). The genealogical reconstructions from intraspecific data were represented through haplotype network using the media-joining algorithm (MJ) (Saitou \& Nei 1987; Bandelt et al. 1999) implemented in the PopART software (Leigh \& Bryant 2015).

\section{Genetic structure}

To describe the genetic structure of $A$. spatuligera, FST (haplotypes frequencies) were calculated among groups (PP and IA). Significance of FST values was based on 10000 permutations. Additionally, to detect geographical structure among groups an Analysis of Molecular Variance (AMOVA, Dupanloup et al. 2002) was performed. In a hierarchical analysis of genetic variation, the genetic structure was divided 
into three components: Fst (genetic structure among all the populations), Fsc (genetic structure within PP and IA) and Fct (genetic structure between PP and IA), estimated trough the number of differences between haplotypes by biogeographic provinces. Both analysis were performed in Arlequin 3.5 (Excoffier \& Lischer 2010).

In addition, the migration pattern was determined by analyzing the genetic relationships based on coalescent theory. The immigration rates (in each direction) between groups were estimated to evaluate gene flow between them using Bayesian inference implemented at MIGRATE- $n$ version 3.2.17 software (Beerli 2011). We compared the default model of asymmetric migration rates with a panmictic model of symmetric migration rates through Bayes Factor (Kass \& Raftery 1995), to determine which model provided the best fit for the data. Using a uniform distribution as a prior and the unique default model F84 (nucleotidic sustitution model), a posteriori probability distribution of parameters $\Theta=x \times \mathrm{Ne} \times$ $\mathrm{u}$ (where, $\mathrm{x}$ : ploid and inheritance of the data, Ne: population effective size, $\mu$ mutation rate by site by generation) and $M=m / \mu$ ( $m$ is the rate of immigrants divided by $\mu$, and $M$ is a measure of how much more important immigration is in relation to the mutation to bring new variants at the population) were estimated. By the multiplication of these parameters $(\Theta \times M)$ the number of immigrants per generation was obtained ( $x \times \mathrm{Ne} \times \mathrm{m}$, Beerli 2011). Long Markov chain Monte Carlo (MCMC) with 5 iterations based on 50000 steps recorded in 100 increments (cycles), runs with different static temperatures (1.0, 1.5, 4.0 and 5) were used, shaping a landscape defined by the probability of 25000000 visited genealogies, where the first $10 \%$ of those genealogies were discarded because they did not reach the convergence zone in the maximum likelihood values on the runs of MCMC (Pardo-Gandarillas 2012).

Demographic inference

Tajima's D and Fu's Fs indices and their corresponding $\mathrm{p}$-values were calculated to detect deviation from WrightFisher mutation-drift equilibrium caused by population expansions, bottlenecks or selection events registered in the past, under neutrality hypotheses (Tajima 1989; Fu 1997) using Arlequin 3.5 (Excoffier \& Lischer 2010). In addition, a mismatch distribution was constructed and compared with a unimodal distribution expected under an instant population growth model (Rogers \& Harpending 1992) using DNAsp 5.1 (Librado \& Rozas 2009).

To further assess on the demographic history of $A$. spatuligera, the time from the demographic expansion under the sudden expansion model (Schneider \& Excoffier 1999) was estimated using the formula $\mathrm{T}=2 \mathrm{ut}$, where the parameter $\mathrm{T}$ is an estimate of time after the expansion in mutational units, obtained in Arlequin, and $u$ is the substitution rate by lineage $(u=2 \mu \mathrm{k} ; \mu=$ mutation rate, $\mathrm{k}=$ nucleotide length of the fragment analyzed). To estimate a period of time, we used two substitution rates for $\mathrm{COI}$ sequences: $0.51 \%$ by $\mathrm{Ma}$ and $0.72 \%$ by $\mathrm{Ma}$ (Lee et al. 2004). These rates were amplified 10 times (5.1\% and $7.2 \%)$, considering the time-dependence correction related to molecular rates at population level proposed by Ho et al. (2005).

\section{RESULTS}

\section{DIVERSITY INDEXES}

A data set that includes 140 sequences with an extension of $630 \mathrm{bp}$ was obtained for A. spatuligera. We observe low levels of genetic diversity across the SEP, with 78 polymorphic sites that represent 25 haplotypes (Table 2).

The genealogical relationships obtained through the Median-Joining Network showed a star-like pattern; a central high frequency haplotype (H1) from which low frequency or unique haplotypes emerge, separated by one or two mutational steps (Fig. 2). Haplotype $\mathrm{H} 1$ was the most common and widely distributed geographically along the SEP, represented by 114 of the 140 individuals (81.5\%). At a lower frequency (1.4\%), H3 was shared and represented by a single individual in each location. In a biogeographic scenario, 19 haplotypes were exclusive to the PP and 4 to the IA, all at a low frequency and present in a single individual, except $\mathrm{H} 7$ that was present in 2 PP individuals.

TABLE 2. Estimated diversity indexes for A. spatuligera groups. / Índices de diversidad estimados por grupos para A. spatuligera.

\begin{tabular}{lrrrccc}
\hline Groups & N & S & H & Hd & K & $\mathbf{~}$ \\
\hline Peruvian Province & 110 & 70 & 21 & 0.34662 & 1.61218 & 0.00256 \\
Intermediate Area & 30 & 15 & 6 & 0.31031 & 1.24368 & 0.00197 \\
Total & 140 & 78 & 25 & 0.33782 & 1.53556 & 0.00244 \\
\hline
\end{tabular}

$\mathrm{N}$, number of individuals per groups; S, number of polymorphic sites; $\mathrm{H}$, number of haplotypes; Hd, haplotype diversity; k, mean pairwise differences; $\Pi$, nucleotide diversity. / N, Número de individuos por grupo; S, Sitios Polimórficos; H, Número de Haplotipos; Hd, Diversidad Haplotípica; k, Número promedio de diferencias entre pares de secuencias; $\Pi$, Diversidad Nucleotídica. 


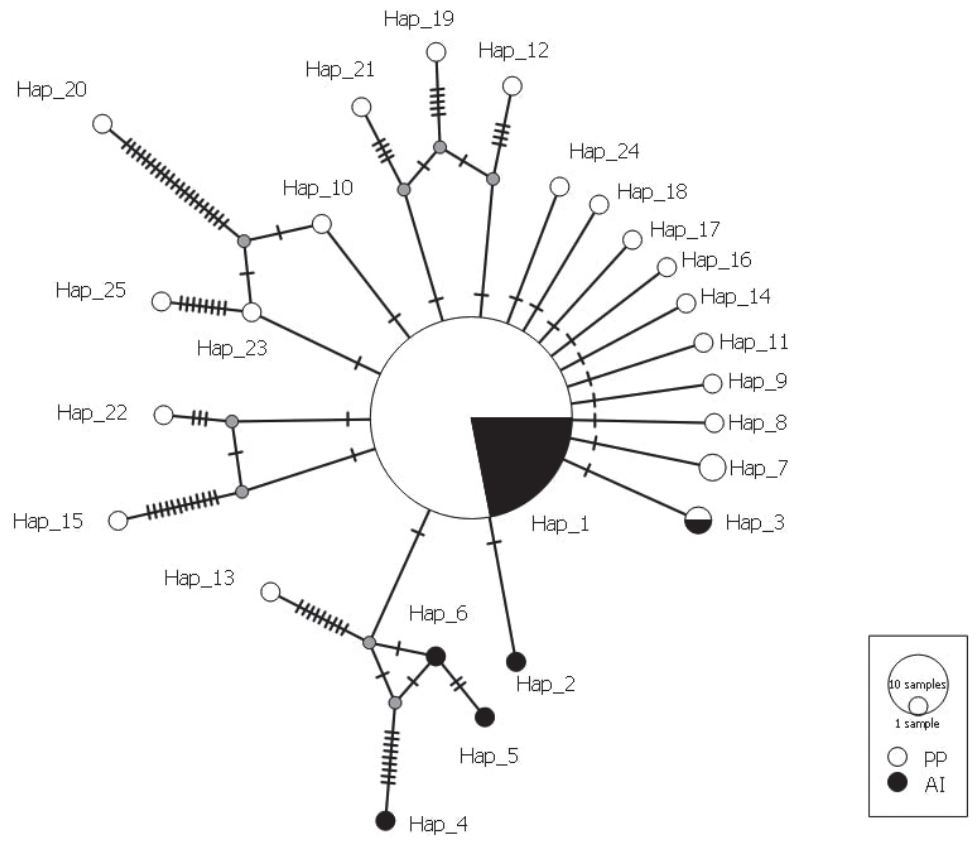

Figure 2. Haplotype network of A. spatuligera grouped by biogeographic provinces (PP: Peruvian Province, IA: Intermediate Area). / Red de Haplotipos de A. spatuligera agrupadas por provincias biogeográficas (PP: Provincia Peruviana, Al: Área Intermedia).

TABLE 3. AMOVA estimated fixation indexes for Arbacia spatuligera through the SEP. / Estimación de índices de fijación obtenidos a través de un AMOVA para Arbacia spatuligera a lo largo del PSE.

\begin{tabular}{lcccccc}
\hline Source of variation & d.f. & $\begin{array}{c}\text { Sum of } \\
\text { squares }\end{array}$ & $\begin{array}{c}\text { Variance } \\
\text { components }\end{array}$ & $\begin{array}{c}\text { Percentaje of } \\
\text { variation }\end{array}$ & $\begin{array}{c}\text { Fixation } \\
\text { index }\end{array}$ & p-value \\
\hline Among biogeographic groups & 2 & 0.88 & -0.00756 & -4.61 & Fct $=-0.046$ & 1.000 \\
Between populations within groups & 3 & 1.215 & 0.00931 & 5.61 & Fsc $=0.053$ & 0.018 \\
Among populations & 135 & 22.176 & 0.16427 & 99.0 & Fst=0.009 & 0.008 \\
\hline
\end{tabular}

\section{Genetic structure}

Fst showed low and no significant values (Fst $=-0.01365$, p-value $=0.9789)$. In concordance, AMOVA performed between PP and IA, indicated an absence of genetic structure (99\% of the variation was within populations) (Table 3 ).

Regarding the comparison between the asymmetric and symmetric migration models, the respective log marginal likelihoods were -1621.760124 and -1627.166031. Using the guidelines of Kass \& Raftery (1995), our result was greater than 2 (LBF = 10.811814), which indicates that our data better fit the asymmetric model. This model showed that the number of migrants estimated per generation in time, through Bayesian analyses between PP and IA, is higher towards the north (14 migrants from IA to PP per generation) (Table 4).

\section{Demographic INFERENCE}

Tajima's D neutrality tests values were negative and significant, indicating an excess of low frequency polymorphisms, and suggest a recent demographic expansion of $A$. spatuligera. Fu's Fs values were negative but non-significant (Table 5). The distribution of pairwise differences among sequences was L-shaped (Fig. 3). The mismatch distribution did not differ from expected sudden growth-decline model (Raggedness, $r=0.2625 ; p<0.05)$, as a signal of recent demographic expansion. According to the growth model and estimated from parameters obtained for $A$. spatuligera (Tau = 2ut: 3 ), and two mutation rates (5.1\% y $7.2 \%$ per Mya), sudden expansion time was estimated ca. 47.000-33.000 years ago, during the Quaternary. 
TABLE 4. Number of migrants per generation $(x \times N e \times m)$ of Arbacia spatuligera between provinces IA and PP of the SEP, obteined from the multiplication of the a posteriori values of the distribution of parameters $\Theta$ and M. / Número de migrantes por generación $(x \times N e x$ m) para Arbacia spatuligera entre las provincias IA y PP del PSE, obtenidos a partir de la multiplicación de los valores a posteriori de la distribución de los parámetros $\Theta$ y $\mathrm{M}$.

\begin{tabular}{|c|c|c|c|c|c|c|c|c|}
\hline Parameter & $2.50 \%$ & $25.00 \%$ & Mode & $75.00 \%$ & $97.50 \%$ & Median & Mean & \\
\hline Q 1 & 0.01253 & 0.01620 & 0.02050 & 0.02553 & 0.05100 & 0.02397 & 0.03327 & \\
\hline Q 2 & 0.00060 & 0.00267 & 0.00523 & 0.01120 & 0.04673 & 0.01037 & 0.01529 & $\mathrm{M}^{*} \mathrm{Q}=\mathrm{N}$ \\
\hline$m^{I A->P P}$ & 68.0 & 110.0 & 179.7 & 259.3 & 376.0 & 240.3 & 429.3 & 14.28 \\
\hline${ }_{M} P P->\mid A$ & 443.3 & 782.0 & 980.3 & 993.3 & 1000.0 & 789.0 & 762.1 & 11.65 \\
\hline
\end{tabular}

TABLE 5. Estimated neutrality tests for Arbacia spatuligera and its p-values. / Test de neutralidad estimado para Arbacia spatuligera y sus respectivos valores de significancia.

\begin{tabular}{lcccc}
\hline Group & Tajima's D & p value & Fu's Fs & P value \\
\hline Peruvian Province & $-2.86953^{* *}$ & $<0.01$ & -14.040 & $>0.05$ \\
Intermediate Area & $-2.35036^{* *}$ & $<0.01$ & -1.002 & $>0.05$ \\
Total & $-2.86776^{* *}$ & $<0.01$ & -19.947 & $>0.05$ \\
\hline
\end{tabular}

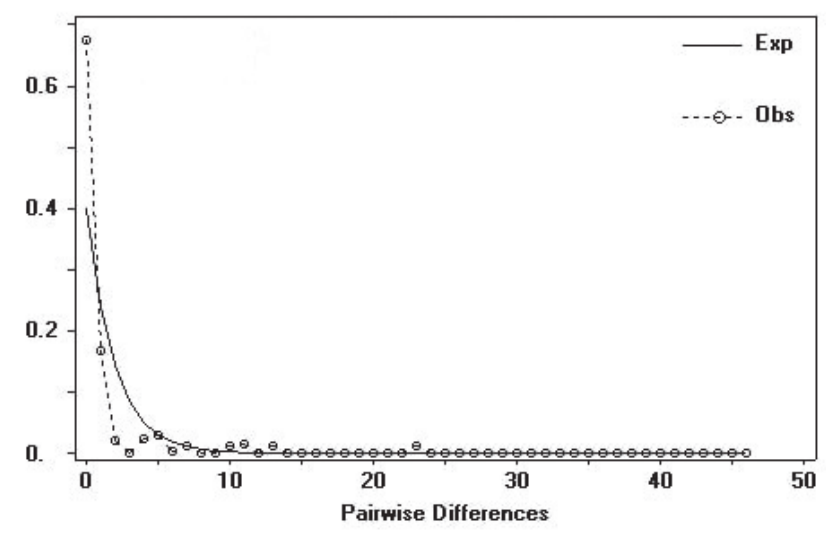

FIGURE 3. Mismatch distribution of observed and expected pairwise differences among mtDNA COI sequences of Arbacia spatuligera from the SEP. / Distribución de desajuste entre pares de secuencias de $A$. spatuligera en el PSE.

\section{DISCUSSION}

The high gene flow proposed for species with a high dispersal capability among their populations (Shanks et al. 2003), helps to diminish the effect of genetic drift (the main way to lose genetic diversity) and homogenizes high levels of genetic diversity (i.e. Hedgecock 1986; Bohonak 1999; Kyle \& Boulding 2000; Lee \& Boulding 2009; Haye et al. 2014). Contrary to what was expected under the "connectivity paradigm", we found an unexpectedly low genetic diversity for A. spatuligera in the SEP. The low genetic diversity found can be due to: i) the smaller larval dispersal period of $A$. spatuligera ( 1 month) in comparison to other invertebrates (e.g., Tetrapygus niger and Concholepas concholepas with $\sim 3$ months, Haye et al. 2014; Cárdenas et al. 2009) or, ii) Other processes, such as genetic bottlenecks, that reduces the effective population size and makes the genetic drift more intense. Although our results suggest a recent demographic expansion, it is possible that A. spatuligera larvae are experiencing a lower rate of swimming and non-swimming larvae settlement due to the changing climate (Aiken et al. 2011), or even, could be inhabiting a suboptimal place at a physiological or ecological level, which would maintain a low effective size so, the gene flow detected does not manage to recover genetic diversity (Bohonak 1999).

The observed star-like haplotype network for A. spatuligera reflects a genealogy pattern consistent with populations that have undergone a recent population expansion after a bottleneck (Slatkin \& Hudson 1991). Haye et al. (2014) report a similar network patterns for the crustaceans Emerita analoga and Petrolisthes violaceus and the echinoderms Heliaster helianthus and Tetrapygus niger, proposing that the dispersal potential is a key factor for the phylogeographic patterns found in the SEP, giving two main explanations for these patterns. The first one is that dispersal potential is a robust predictor of genetic structure for the SEP coastline and can 
be used as a proxy for connectivity in this area. The second one is that low potential dispersers show genetic signatures of historical barriers and events, and high potential dispersers show genetic signatures of recent barriers or events. According to this, A. spatuligera shows all the signatures of a high disperser.

The absence of genetic structure across ca. $3.200 \mathrm{~km}$ of coast, which includes a biogeographic break documented at $\sim 30^{\circ} \mathrm{S}$, found for A. spatuligera is opposed to the relation between biogeographic barriers and phylogeographic breaks proposed by Avise (2000). This absence of genetic structure reflects a high connectivity, supported by the migration analysis that indicates a higher flow towards the PP, which also could be related to the influence of the HCS, according to the fundamental role that oceanic currents have over gene flow and dispersal potential (Cowen et al. 2000; Gaylord \& Gaines 2000). Both factors, dispersal potential and oceanic currents, explain the absence of genetic structure in some barnacles, gastropods and echinoderms (Wares \& Cunningham 2001; White et al. 2010). In the SEP the HCS is divided into three arms: the equatorward Chilean Coastal Current (CCC); the 100-300 km offshore poleward Peru-Chile Countercurrent (PCC); and the equatorward Oceanic Chile-Peru Current (OCPC) (Penven et al. 2005; Thiel et al. 2007). Camus (2001) argues that these currents are responsible for the SEP biogeography and are the main reason for the IA biota's mixed character. We propose that the CCC and OCPC and their respective equatorward $0.2 \mathrm{~ms}^{-1}$ and $0.15 \mathrm{~ms}^{-1}$ flow (Marín \& Delgado 2007; Fuenzalida et al. 2008), behave as a dispersal enhancer to the pelagic larval phase of $A$. spatuligera.

Demographic inferences observed in A. spatuligera are concordant with a scenario of recent population expansion after a bottleneck or founder effect (Slatkin \& Hudson 1991). Bottlenecks affect population's effective size ( $\mathrm{Ne}$ ) by reducing it, inducing stronger genetic drift effects over them, therefore losing genetic diversity (Kyle \& Boulding 2000; Lee \& Boulding 2009; Ibáñez et al. 2011; Haye et al. 2014). In $A$. spatuligera, the recent population expansion and/ or low mutation rates have not yet allowed this species to increase genetic diversity. Marine pelagic ecosystem species reflect genetic signals from persistent processes through larger time scales (Janko et al. 2007), contrary to coastal species that show genetic signals of recent events such as the LGM (Wares \& Cunningham 2001). In the SEP, the $30^{\circ} \mathrm{S}$ biogeographic break could be a historical break with no influence over high-dispersal potential species (Cárdenas et al. 2009; Ibáñez et al. 2011; Haye et al. 2014). The recent date of demographic expansion estimated for A. spatuligera (33 - $47 \mathrm{Ka}$ ), although speculative, is interesting due to its coincidence with the last glacial period during a phase called the Marine Isotope Stage 3 (MIS3, 60-30 cal ka BP). MIS3 is characterized by particular glacio-climatic events that caused rapid ocean climate variability (Zumaque et al. 2012). Climatic phases known as the Dansgaard-Oeschger cycles (i.e. Bond et al. 1993; Dansgaard et al. 1993) are recognized especially during the MIS3 and correspond to oscillations between warm (Gls for Greenland Interstadials) and cold (GSs for Greenland Stadials) climatic phases. In turn, these cycles are punctuated by abrupt events, called Heinrich Events (HEs) that correspond to some of the DO coldest phases (Zumaque et al. 2012). Among the HEs, the HEs3 and HEs4 could help explain our results, dated at 30 and $\sim 40$ Ka respectively (Rabassa \& Ponce 2013). One of the main process that can arise from the abrupt cooling event, for shallow benthic species of a narrow continental shelf of the PSE (such as A. spatuligera), is the loss of habitat due to the decrease in the global sea level. Lambeck \& Chappell (2001) and Chappell (2002), proposed rapid decrease in sea level to $\sim 120$ meters, about $\sim 30 \mathrm{Ka}$, at the end of MIS3.

\section{Conclusions}

According to our results, A. spatuligera is a species with no evidence of genetic structure along the SEP, despite the biogeographic break described at $30^{\circ} \mathrm{S}$, and with a low genetic diversity. The absence of genetic structure and the role of HCS as a dispersal enhancer lead us to propose that $A$. spatuligera qualifies as a high disperser species, and its demographic history also reflects a response pattern to more recent climatic events. Our results support the proposed hypothesis related that phylogeographic patterns of organisms inhabiting the SEP are strongly influenced by their dispersal potential, being a useful proxy for genetic structure. However, because of the unexpectedly low genetic diversity found, more detailed analyses are needed for a complete understanding of the processes involved in evolutionary history of $A$. spatuligera.

\section{ACKNOWLEDGEMENTS}

The authors thank the financing of the projects: FAIP to AM and AD; VRID Initiation 217.113.093-1 OIN to AD and PIA CONICYT ACT172065 to AD and EP.

\section{REFERENCES}

Aiken, C.M., Navarrete, S.A., Pelegrí, J.L. 2011. Potential changes in larval dispersal and alongshore connectivity on the central Chilean coast due to an altered wind climate. Journal of Geophysical Research 116: G04026. 
Atkinson, L.P., Valle-Levinson, A., Figueroa, D., De Pol-Holz, R., Gallardo, V.A., Schneider, W., Blanco, J.L., Schmidt, M. 2002. Oceanic observations in Chilean coastal waters between Valdivia and Concepción. Journal of Geophysical Research 107(C7, 2081): 1-14.

Avise, J.C., Arnold, J., Ball, R.M., Bermingham, E., Lamb, T., Neigel, J.E., Reeb, C.A., Saunders, N.C. 1987. Intraspecific phylogeography: the mitochondrial DNA bridge between population genetics and systematics, Annual Review of Ecology and Systematics 18: 489-522.

Avise, J.C. 2000. Phylogeography: The History and Formation of Species. Harvard University Press, Cambridge, MA. 447pp.

Ayre, D.J., Minchinton, T.E., Perrin, C. 2009. Does life history predict past and current connectivity for rocky intertidal invertebrates across a marine biogeographic barrier? Molecular Ecology 18(9): 1887-1903.

Bandelt, H.J., Forster, P., Röhl, A. 1999. Median-joining networks for inferring intraspecific phylogenies. Molecular Biology and Evolution 16(1): 37-48.

Bay-Schmith, E.1981. Ciclo anual de reproducción de Arbacia spatuligera (Valenciennes 1846) en la Bahía de Concepción Chile (Echinoidea, Arbaciidae). Boletín de la Sociedad de Biología de Concepción 51: 47-59.

Beerli, P. 2011. MIGRATE-n Version 3.2.17: Migrate Documentation. http://popgen.csit.fsu.edu/migrate.download.html.

Bernal, P., Robles, F.L., Rojas, O. 1982. Variabilidad física y biológica de la región meridional del sistema de corrientes Chile-Perú. pp 75-102 In: Castilla J.C. (Ed) Monografías biológicas. Bases biológicas para el uso y manejo de recursos naturales renovables: recursos biológicos marinos, Vol 2. Facultad de Ciencias Biológicas, Pontificia Universidad Católica de Chile.

Bohonak, A. 1999. Dispersal, gene flow, and population structure. The Quarterly Review of Biology 74: 21-45.

Bond, G., Broecker, W., Johnsen, S., McManus, J., Labeyrie, L., Jouzel, J., Bonani, G. 1993. Correlations between climate records from North Atlantic sediments and Greenland ice. Nature 365: 143-147.

Camus, P. 2001. Biogeografía marina de Chile continental. Revista Chilena de Historia Natural 74(3): 587-617.

Cárdenas, L., Castilla, J.C., Viard, F., Bellwood, D. 2009. A phylogeographical analysis across three biogeographical provinces of the south-eastern Pacific: the case of the marine gastropod Concholepas concholepas. Journal of Biogeography 36(5): 969-981.

Chappell, J. 2002. Sea level changes forced ice breakouts in the Last Glacial cycle: new results from coral terraces, Quaternary Science Reviews 21: 1229-1240.

Cowen, R., Sponaugle, S. 2009. Larval Dispersal and Marine
Population Connectivity. Annual Review Marine Science 1: 443-66.

Cowen, R.K., Lwiza, K.M., Sponaugle, S., Paris, C.B., Olson, D.B. 2000. Connectivity of Marine Populations: Open or Closed? Science 287(5454): 857-859.

Dansgaard, W., Johnsen, S.J., Clausen, H.B., Dahl-Jengen, D., Gundestrup, N.S., Hammer, C.U., Hvidberg, C.S., Steffensen, J.P., Sveinbjörnsdottir, A.E., Jouzel, J., Bond, G. 1993. Evidence for general instability of past climate from 250-kyr ice-core record. Nature 364: 218-220.

Debenham, P., Brzezinski, M., Foltz, K., Gaines, S. 2000. Genetic structure of of populations of the red sea urchin Strongylocentrotus franciscanus. Journal of Experimental Marine Biology and Ecology 253: 49-62.

Dupanloup, I., Schneider, S., Excoffier, L. 2002. A simulated annealing approach to define the genetic structure of populations. Molecular Ecology 11: 2571-2581.

Duran, S., Palacín, C., Becerro, M., Turon, X., Giribet, G. 2004. Genetic diversity and population structure of the commercially harvested sea urchin Paracentrotus lividus (Echinodermata, Echinoidea). Molecular Ecology 13: 3317-3328.

Excoffier, L., Lischer, H.E.L. 2010. Arlequin suite ver 3.5: A new series of programs to perform population genetics analyses under Linux and Windows. Molecular Ecology Resources 10(3): 564-567.

Filatov, D.A. 2009. Processing and population genetic analysis of multigenic datasets with ProSeq3 software. Bioinformatics 25: 3189-3190.

Fu, Y-X. 1997. Statistical tests of neutrality of mutations against population growth, hitchhiking and background selection. Genetics 147(2): 915-925.

Fuenzalida, R., Schneider, W., Garcés-Vargas, J., Bravo, L. 2008. Satellite altimetry data reveal jet-like dynamics of the Humboldt Current. JGR Oceans 113(C7).

Fuenzalida, R., Schneider, W., Garcés-Vargas, J., Brazo, L., Lange, C. 2009. Vertical and horizontal extensión of the oxygen mínimum zone in the Eastern South Pacific Ocean. Deep Sea Research II 56: 992-1003.

Gawarkiewicz, G., Monismith, S., Largier, J. 2007. Observing Larval Transport Processes Affecting Population Connectivity: Progress and Challenges. Oceanography 20(3): 40-53.

Gaylord, B., Gaines, S.D. 2000. Temperature or Transport? Range Limits in Marine Species Mediated Solely by Flow. The American Naturalist 155(6): 769-789.

Goldson, A., Hughes, R., Gliddon, C. 2001. Population genetic consequences of larval dispersal mode and hydrography: a case study with bryozoans. Marine Biology 138(5): 1037-1042. 
Grosberg, R., Cunningham, C. 2001. Genetic structure in the sea: From populations to communities. En: Bertness, M.D., Gaines, S.D., Hay, M.E. (Eds.) Marine Community Ecology: 61-84. Sinauer Associates, Sunderland, MA, USA.

Harvey, E.B. 1956. The American Arbacia and other sea urchins. Princeton University Press, Princeton. 296 pp.

Haye, P.A., Segovia, N.I., Muñoz-Herrera, N.C., Gálvez, F.E., Martínez, A., Meynard, A., Pardo-Gandarillas, M.C., Poulin, E., Faugeron, S. 2014. Phylogeographic Structure in Benthic Marine Invertebrates of the Southeast Pacific Coast of Chile with Differing Dispersal Potential. PLoS ONE 9(2): e88613.

Hedgecock, D. 1986. Is gene flow from pelagic larval dispersal important in the adaptation and evolution of marine invertebrates? Bulletin of Marine Science 39(2): 550-564.

Hereu, B., Zavala, M., Linares, C. 2004 Temporal and spatial variability in settlement of the sea urchin Paracentrotus lividus in the NW Mediaterranean. Marine Biology 144: 1011-1018.

Ho, S.Y., Phillips, M.J., Cooper, A., Drummond, A.J. 2005. Time dependency of molecular rate estimates and systematic overestimation of recent divergence times. Molecular Biology and Evolution 22(7): 1561-1568.

Hooker, Y., Prieto-Ríos, E., Solís-Marín, F. 2013. Echinoderms of Perú. In: Echinoderms Research and Diversity in Latin America. pp. 277-299. Springer-Verlag, Berlin, Heidelberg.

Ibáñez, C., Cubillos, L., Tafur, R., Argüelles, J., Yamashiro, C., Poulin, E. 2011. Genetic diversity and demographic history of Dosidicus gigas (Cephalopoda: Ommastrephidae) in the Humboldt Current System. Marine Ecology Progress Series 431: 163-171.

Iuri, V., Patti, F., Procaccini, G. 2007. Phylogeography of the sea urchin Paracentrotus lividus (Lamarck) (Echinodermata: Echinoidea): First insights from the south Tyrrhenian Sea. Biodiversity in Enclosed Seas and Artificial Marine Habitats Developments in Hydrobiology 193: 77-84.

Janko, K., Lecointre, G., DeVries, A., Coulous, A., Cruaud, C., Marshal, C. 2007. Did glacial advances during the Pleistocene influence differently the demographic histories of benthic and pelagic Antarctic shelf fishes? Inferences from intraspecific mitochondrial and nuclear DNA sequence diversity. BMC Evolutionary Biology 12(7): 203-220.

Kass, R.E., Raftery A.E. 1995. Bayes factors. Journal of the American Statistical Association 90(430): 773-795.

Kyle, C., Boulding, E. 2000. Comparative population genetic structure of marine gastropods (Littorina spp.) with and without pelagic larval dispersal. Marine Biology 137: 835-845.

Lambeck, K., Chappell J. 2001. Sea Level Change Through the
Last Glacial Cycle. Science 292: 679-686.

Larraín, A. 1975. Los equinoideos regulares fósiles y recientes de Chile. Gayana Zoología 35: 5-189.

Larrain, A., Riveros, A., Silva, J., Bay-Schmith, E. 1999. Toxicity of metals and pesticides using the sperm cell bioassay with the sea urchin Arbacia spatuligera. Bulletin of Environmental Contamination and Toxicology 62: 749757.

Lee, H., Boulding, E. 2009. Spatial and temporal population genetic structure of four northeastern Pacific littorinid gastropods: the effect of mode of larval development on variation at one mitochondrial and two nuclear DNA markers. Molecular Ecology 18: 2165-2184.

Lee, Y., Song, M., Lee, S., Leon, R., Godoy, S.O., Canete, I. 2004. Molecular phylogeny and divergence time of the Antartic sea urchin (Sterechinus neumayeri) in relations to the South American sea urchins. Antarctic Science 16(1): 29-36.

Leigh, J.W., Bryant, D. 2015. PopART: Full-feature software for haplotype network construction. Methods in Ecology and Evolution 6(9): 1110-1116.

Lessios, H.A., Kessing, B.D., Robertson, D.R., Paulay, G. 1999. Phylogeography of the pantropical sea urchin Eucidaris in relation to land barriers and ocean current. Evolution 53(3): 806-817.

Lessios, H., Kessing, B., Pearse, J. 2001. Population structure and speciation in tropical seas: global phylogeography of the sea urchin Diadema. Evolution 55: 955-975.

Lessios, H., Kane, J., Robertson, J.D. 2003. Phylogeography of the pantropical sea urchin Tripneustes: contrasting patterns of population structure between oceans. Evolution 57: 2026-2036.

Lessios, H.A., Lockhart, R., Collin, R., Sotil, G., Sanchez-Jerez, P., Zigler, K.S., Perez, A.F., Garrido, M.J., Geyer, L.B., Bernardi, G., Vacquier, V.D., Haroun, R., Kessing, B.D. 2012 Phylogeography and bindin evolution in Arbacia, a sea urchin genus with an unusual distribution. Molecular Ecology 21(1): 130-44.

Librado, P., Rozas, J. 2009. DnaSP v5: A software for comprehensive analysis of DNA polymorphism data. Bioinformatics (25): 1451-1452.

Maltagliati, F., Di Giuseppe, G., Barbieri, M., Castelli, M., Dini, F. 2010. Phylogeography and genetic structure of the edible sea urchin Paracentrotus lividus (Echinodermata: Echinoidea) inferred from the mitochondrial cytochrome $b$ gene. Biological Journal of the Linnean Society 100: 910-923.

Marín, V.H., Delgado, L.E. 2007. Lagrangian observations of surface coastal flows North of $30^{\circ} \mathrm{S}$ in the Humboldt Current system. Continental Shelf Research 27(6): 731743. 
McCartney, M., Keller, G., Lessios, H. 2000. Dispersal barriers in tropical oceans and speciation in Atlantic and Eastern Pacific sea urchin of the genus Echinometra. Molecular Ecology 9: 1391-1400.

McEdward, L., Miner, B. 2001. Larval and life-cycle patterns in echinoderms. Cannadian Journal of Zoology 79: 11251170.

Montecinos, V., Strub, P., Chavez, F., Thomas A., Tarazona J., Baumgartner, T. 2005. Bio-physical interactions off western South America. In: Robinson, A.R., Brink K.H. (Eds) The Sea: 329-390. Harvard University Press, Cambridge, Mass.

Moore, J. 2006. An Introduction to the Invertebrates. $2^{\text {nd }}$ Edition. Cambridge University Press, London, UK, 319 p.

Palumbi, S. 1996. What can molecular genetics contribute to marine biogeography? An urchin's tale. Journal of Experimental Marine Biology and Ecology 203: 75-92.

Palumbi, S. 2003. Population genetics, demographic connectivity, and the design of marine reserves. Ecological Applications 13: 146-158.

Pardo-Gandarillas, M.C. 2012. Aproximaciones filogeográficas para evaluar patrones de conectividad e historia demográfica en dos especies de pulpos, habitantes de distintas provincias biogeográficas de Sudamérica: Importancia de las glaciaciones y de las condiciones oceanográficas contemporáneas. Tesis Doctoral, Universidad de Chile, Chile.

Pechenik, J.A. 1999. On the advantages and disadvantages of larval stages in benthic marine invertebrate life cycles. Marine Ecology Progress Series 177: 268-297.

Pelc, R.A., Warner, R.R., Gaines, S.D. 2009. Geographical patterns of genetic structure in marine species with contrasting life histories. Journal of Biogeography 36(10): 1881-1890.

Penven, P., Echevin, V., Pasapera, J., Colas, F., Tam, J. 2005. Average circulation, seasonal cycle, and mesoscale dynamics of the Peru Current System: A modeling approach. Journal of Geophysical Research 110(C10): 67-87.

Rabassa, J., Ponce, J.F. 2013. The Heinrich and DansgaardOeschger Climatic Events during Marine Isotopic Stage 3: Searching for appropriate times for Human Colonization of The Americas. Quaternary International 299: 94-105.

Rogers, A.R., Harpending, H. 1992. Population growth makes waves in the distribution of pairwise genetic differences. Molecular Biology and Evolution 9(3): 552-569.

Saitou, N., Nei, M. 1987. The neighbor-joining method: A new method for reconstructing phylogenetic trees. Molecular Biology and Evolution 4(4): 406-425.

Sánchez, R., Sepúlveda, R., Brante, A., Cárdenas, L. 2011. Spatial pattern of genetic and morphological diversity in the direct developer Acanthina monodon (Gastropoda:
Mollusca). Marine Ecology Progress Series 434: 121-131.

Scheltema, R.S. 1971. Larval dispersal as a means of genetic exchange between geographically separated populations of shallow water benthic marine gastropods. Biological Bulletin 140: 284-322.

Scheltema, R.S. 1986a. Long-distance dispersal by planktonic larvae of shoal-water benthic invertebrates among central Pacific Islands. Bulletin of Marine Sciences 39: 241-256.

Scheltema, R.S. 1986b. On dispersal and planktonic larvae of benthic invertebrates: an eclectic overview and summary of problems. Bulletin of Marine Sciences 39: 290-322.

Schneider, S., Excoffier, L. 1999. Estimation of past demographic parameters from the distribution of pairwise differences when the mutation rates vary among sites: application to human mitochondrial DNA. Genetics 152(3): 1079-1089.

Shanks, A.L., Grantham, B.A., Carr, M.H. 2003. Propagule dispersal distance and the size and spacing of marine reserves. Ecological Applications 13: S159-S169.

Slatkin, M., Hudson, R.R. 1991. Pairwise Comparisons of Mitochondrial DNA Sequences in Stable and Exponentially Growing Populations. Genetics 129(2): 555-562.

Smith, A. 1997. Echinoderm larvae and phylogeny. Annual Review of Ecology and Systematics 28: 219-241.

Sotka, E., Palumbi, S. 2006. The use of genetic clines to estimate dispersal distances. Ecology 87(5): 1094-1103.

Tajima, F. 1989. Statistical method for testing the neutral mutation hypothesis by DNA polymorphism. Genetics 123(3): 585-595.

Tamura, K., Stecher, G., Peterson, D., Filipski, A., Kumar, S. 2013. MEGA6: molecular evolutionary genetics analysis version 6.0. Molecular Biology and Evolution 30(12): 2725-2729.

Thiel, M., Macaya, E.C., Acuña, E., Arntz, W., Bastias, H., Brokordt, K., Camus, P.A., Castilla, J.C., Castro, L.R., Cortés, M., Dumont, C.P., Escribano, R., Fernandez, M., Gajardo, J.A., Gaymer, C.F., Gomez, I., González, A.E., González, H.E., Haye, P.A., Illanes, J.E., Iriarte, J.K., Lancellott, D.A., Luna-Jorquera, G., Luxoro, C., Manriquez, P.H., Marín, V., Muñoz, P., Navarrete, S.A., Perez, E., Poulin, E., Sellanes, J., Sepúlveda, H.H., Stotz, W., Tala, F., Thomas, A., Vargas, C.A., Vasquez, J.A., Vega, J.M. 2007. The Humboldt Current System of Northern and Central Chile: oceanographic processes, ecological interactions and socioeconomic feedback. Oceanography and Marine Biology: An Annual Review 45: 195-344.

Todd, C., Lambert, W., Thorpe, J. 1998. The genetic structure of intertidal populations of two species of nudibranch molluscs with planktotrophic and pelagic lecithotrophic larval stages: are pelagic larvae "for" dispersal? Journal of Experimental Marine Biology and Ecology 228: 1-28.

Ulloa, O., Pantoja, S. 2009. The oxygen minimum zone of the 
eastern South Pacific. Deep-Sea Research II (56): 987 991.

Wares, J.P., Cunningham, C.W. 2001. Phylogeography and historical ecology of the North Atlantic intertidal. Evolution 55(12): 2455-2569.

White, C., Selkoe, K.A., Watson, J., Siegel, D.A., Zacherl, D.C., Toonen, R.J. 2010. Ocean currents help explain population genetic structure. Proceedings of the Royal Society $B$ 277(1688): 1685-1694.
Zakas, C., Binford, J., Navarrete, S.A., Wares, J.P. 2009. Restricted gene flow in Chilean barnacles reflects an oceanographic and biogeographic transition zone. Marine Ecology Progress Series 394: 165-177.

Zumaque, J., Eynaud, F., Zaragosi, S., Marret, F., Matsuzaki, K.M., Kissel, C., Roche, D.M., Malaizé, B., Michel, E., Billy, I., Richter, T., Palis, E. 2012. An ocean-ice coupled response during the last glacial: a view from a marine isotopic stage 3 record south of the Faeroe Shetland Gateway. Climate of the Past 8: 1997-2017.

Received: 10.01.2019

Accepted: 22.03.2019 